in vivo $33: 11-16(2019)$

doi:10.21873/invivo.11432

Review

\title{
Lack of Awareness of Dietary Sources of Phosphorus Is a Clinical Concern
}

\author{
MICHIKO SHIMADA ${ }^{1}$, YOSHIKO SHUTTO-UCHITA ${ }^{2}$ and HIDEAKI YAMABE ${ }^{3}$ \\ ${ }^{1}$ Department of Cardiology and Nephrology, Hirosaki University Graduate School of Medicine, Hirosaki, Japan; \\ ${ }^{2}$ Tsuchiura Kyodo Hospital Namegata District Medical Center, Namegata, Japan; \\ ${ }^{3}$ EST clinic, Hirosaki, Japan
}

\begin{abstract}
Hyperphosphatemia is a serious complication in patients with chronic kidney disease (CKD), and is associated with more rapid progression as well as higher risk of mortality, and higher rate of cardiovascular disease accidents. CKD patients are usually advised to adopt a low phosphate diet in addition to phosphate-lowering medications, if necessary. However, there is a lack of awareness of the dietary sources of phosphate, especially hidden phosphate intake from phosphate additives in processed foods and carbonated beverages. Appropriate nutritional education could be an effective solution in reducing phosphate toxicity without introducing an additional pill burden or malnutrition.
\end{abstract}

Phosphate is an essential component of the human body (1), however, recent studies have shown the risk of excess phosphate intake in early aging, arteriosclerosis and renal diseases (2-4). In patients with chronic kidney disease (CKD), hyperphosphatemia is associated with higher risk of mortality $(5,6)$ and cardiovascular disease (CVD) which is the most common cause of death in CKD (7). Additionally, hyperphosphatemia has been suggested as being a risk factor for a more rapid progression of CKD (8). CKD patients are, therefore, advised to restrict dietary intake of phosphate, as well as take phosphate-lowering medications to maintain serum phosphate levels in the normal range $(9,10)$. Nevertheless, there has been a lack of interventional studies

This article is freely accessible online.

Correspondence to: Hideaki Yamabe, MD, Ph.D., Professor Emeritus of Hirosaki University,EST clinic, 20-1 Shintatezoe, Fukumura, Hirosaki 036-8082, Japan. Tel: +81 172295500, e-mail: h-yamabe@lapis.plala.or.jp

Key Words: Phosphorus, CKD, hemodialysis, FGF-23, Klotho, food additives, review. demonstrating improved outcomes from restriction of dietary phosphate (11). In this review, we discuss the recent nutritional research related to phosphate toxicity.

\section{Phosphate Toxicity}

Risk of mortality, cardiovascular diseases and CKD progression. Recent studies have revealed the risks of increased serum phosphate levels in aging, atherosclerosis and renal disease (24, 12, 13). Hyperphosphatemia is an independent risk for mortality and CVD in patients with CKD who are undergoing maintenance hemodialysis $(5,6)$. It is also related to mortality and the risk of CVD in non-dialysis CKD patients $(7,13)$. In addition, hyperphosphatemia is associated with a more rapid CKD progression (8). And furthermore, high-normal phosphate levels are also related to an increased risk of CVD (14), and coronary atherosclerosis (15) in patients with normal kidney function. However, the mechanisms of elevated risks associated with CVD-related hyperphosphatemia are not fully understood. Initially, secondary hyperparathyroidism followed by hyperphosphatemia was found to be associated with vascular calcification and myocardial hypertrophy as well as cardiac dysfunction (16). Recent evidence has demonstrated the role of hyperphosphatemia itself in vascular calcification and CKDmineral bone disorder. Phosphorus toxicity is now considered to be the main cause of cardiovascular mortality (17), and, furthermore, it is also toxic to the endothelial cells of blood vessels (18). The increased serum phosphate from excessive consumption of dietary phosphate additives induces increased carotid intima-media thickness $(19,20)$. In addition, elevated dietary phosphate load can also increase fibroblast growth factor23 (FGF-23) concentration, which has been linked to cardiac hypertrophy and adverse cardio-vascular outcomes (21-23).

Possible effects of carbonated drinks on healthy adults with normal kidney function. It is not yet known whether or not the phosphate in common foods and beverages influence 
individuals with normal renal function. In this study, we examined the effect of carbonated drinks in healthy volunteers. The subjects were 55 university students. Thirtyfive of the students, whose average age was 21.2 years, drank $350 \mathrm{ml}$ of carbonated soda and 20 of the students, whose average age was 19.9 years, drank $350 \mathrm{ml}$ of mineral water. Urine samples were collected before and also $2 \mathrm{~h}$ after consumption. Urinary protein and glucose concentrations were determined qualitatively using test paper, while the amounts of urinary phosphate, calcium and creatinine were measured using an auto-analyzer. Urinary phosphate and calcium levels were normalized to creatinine concentration. The mean level of urinary calcium in these 35 volunteers increased significantly after consumption of the carbonated soda, while there was no change in urinary calcium excretion in the 20 control students, who drank water. A $350 \mathrm{ml}$ portion of carbonated soda contains about $50 \mathrm{mg}$ of phosphate and may enhance calcium excretion in normal individuals. This result suggests that a standard soda drink can even influence individuals with normal renal function (24). Moreover, dietary phosphorus overload may be related to various kinds of malignancies such as lung, breast and prostate cancers, since phosphorus burden influences cancer cell growth and metabolism $(3,25,26)$. However, the results of earlier studies have not always been consistent and further research is needed to clarify the underlying molecular connections.

Why does hyperphosphatemia occur in CKD? . Mechanism of hyperphosphatemia in CKD patients is summarized in Figure 1. Levels of serum phosphate are generally regulated by (i) dietary intake (ii) absorption in the intestine, and (iii) reabsorption by the proximal tubules (27). Since renal regulation is crucial in chronic renal insufficiency, reduced glomerular filtration rate (GFR) leads to phosphate retention. Serum phosphate is filtered through the glomerulus into urine and is reabsorbed by the NaPi-2 co-transporter in the proximal tubules (28). The amount of filtered phosphate decreases as glomerular function declines and so hyperphosphatemia is usually observed in various stages of disease of CKD patients and is always present in hemodialysis patients. Serum phosphate levels usually rise when GFR is below about $35 \mathrm{ml} / \mathrm{min}$ per $1.73 \mathrm{~m}^{2}$ (29). Serum calcium levels are related to serum phosphate levels, and the mathematical product of serum phosphate and calcium is concentrations that are usually constant. Therefore, when serum phosphate levels rise, serum calcium levels fall. An injured kidney cannot activate vitamin $\mathrm{D}$ and low vitamin D levels lead to reduced calcium absorption in the intestine. The body tries to correct the low serum calcium levels by releasing parathyroid hormone (PTH) to raise serum calcium, which releases calcium from bones. As a result, bones become weak and sometimes bone pain can occur. Ectopic calcification is often observed in various human organs, such as joints, sub-dermal soft tissue, conjunctiva membranes, lungs and arteries (30). Arterial calcification accelerates arteriosclerosis, while osteomalacia is a particularly serious problem in children of short stature (31).

Phosphate retention enhances the release of FGF-23 from bone (32). This FGF-23 functions in conjunction with the enzyme klotho in tubular cells to inhibit the reabsorption of phosphate in proximal tubules (33). FGF-23 also potently suppresses vitamin D activity, possibly to limit further gastrointestinal absorption of phosphate, resulting in diminished calcium absorption and further stimulation of PTH. Reduced renal function can no longer support further phosphate excretion, and serum PTH levels rise with this reduction, thus serum levels of phosphate increase further as renal function declines.

A high level of serum FGF-23 is the earliest marker of renal dysfunction rather than overt hyperphosphatemia itself (34). Recent studies have reported that serum FGF-23 levels anticipate congestive heart failure and are related to left ventricular hypertrophy $(35,36)$, making these levels an independent risk factor for CVD (32) and mortality (37). Thus, phosphate restriction may need to be initiated even earlier, so that FGF-23 can be maintained within normal limits.

Klotho is a single-pass transmembrane protein and is expressed in multiple tissues but its expression is particularly high in the kidney (33). It is strongly expressed in the renal tubules in mouse, rat, and human kidneys (38), and functions as a receptor for FGF-23 to promote renal phosphate excretion and to reduce serum levels of vitamin D. Klotho expression reduces as renal function declines, and so phosphate retention influences klotho expression (39). A high serum klotho level may decrease the severity of CKD and mineral bone disorder in maintenance of hemodialysis patients with low mineral density (40). Klotho also has various other functions that are unrelated to CKD progression, but that are related rather to human aging (41).

Vitamin D is known to control skeletal pathophysiology, regulating calcium and phosphorus and bone remodeling along with other calcium regulating hormones. Vitamin D deficiency has been associated with promoting atherosclerosis, vascular calcification and cardiovascular disease (42).

\section{Possible Measures to Reduce Phosphate Burden}

Is phosphate restriction harmful? There is a concern that phosphate restriction may result in worse outcomes (43-46). Previously, phosphate restriction placed more emphasis on protein restriction, which may lead to malnutrition, and an even worse prognosis, since malnutrition results in high mortality in hemodialysis patients (47). Therefore, we should instead consider reducing phosphate intake without restriction of protein consumption. So, it is important to reduce the phosphate-to-protein ratio. This lower ratio is 


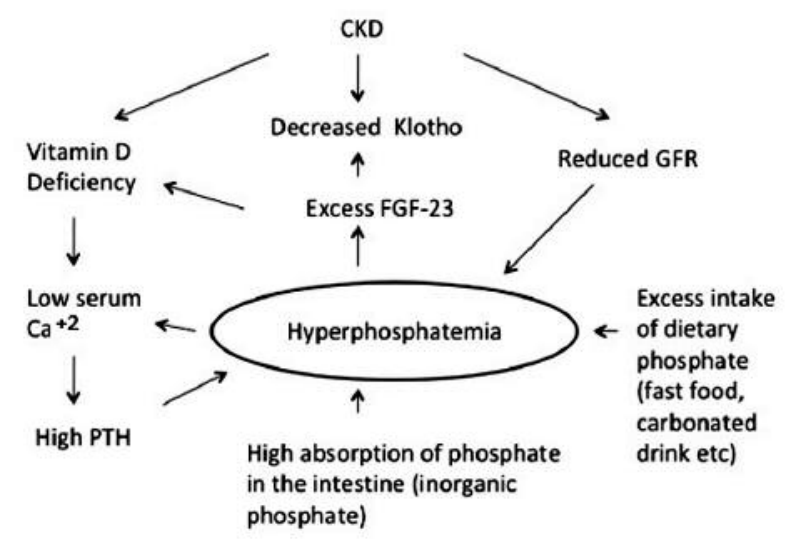

Figure 1. Mechanism of hyperphosphatemia in CKD patients.

crucial because a high ratio is related to increased mortality (48). These concerns can be minimized by reduction of phosphate additives instead restriction of the regular diet.

Hidden phosphate intake from food additives. Phosphate is one of the basic components of our daily food, and the phosphate content of food is primarily derived from protein (49). Nevertheless, in recent years, phosphate has been used as an additive in processed foods and beverages. These additives are used for many purposes e.g. as preservatives, acidifiers, curing agents, $\mathrm{pH}$ buffers, and emulsifying agents (50). Fast food, ready-to-eat packaged foods, cola and carbonated beverages, processed meats, in particular, often contain large amounts of phosphate additives. A recent study has showed that dairy products and cereals/grains containing inorganic phosphate additives significantly increase serum phosphorus concentrations despite them being less frequently consumed than phosphate additive-free foods (51).

Another important factor is food labeling. At present, it is not mandatory to report the amount of phosphate of the nutritional facts on the packaging, and so more phosphate is unknowingly consumed than can be estimated from nutritional databases. Therefore, it would be helpful to know what kind of food or beverages contain high amounts of phosphate.

The quality of phosphate is a key. The American groups have reported that dietary phosphorus intake increased between 2001 and 2014 in the USA. Grains were the largest dietary phosphorus source, followed by meats, and milk products. Soft drinks accounted for just 3.3\% of total dietary phosphorus and were a minor contribution to total phosphorus intake (52). However, the inorganic phosphate compounds used as phosphate additives are absorbed extremely efficiently (90-100\%) in the gut (53), while only
$40-60 \%$ of organic phosphate originating from animal protein, and $20-50 \%$ of phytate-based organic phosphate from vegetables is absorbed (48). In addition, each food item has a different phosphate-to-protein ratio, which is potentially helpful information to enable a consumer to make better choices with respect to phosphate restriction (47). Indeed, both higher dietary food intake and higher phosphorus-to-protein ratios, estimated from food frequency questionnaires were associated with increased mortality in maintenance of hemodialysis patients (48). Additionally, restriction of phosphate levels by educating individuals to avoid phosphate additives and fast food has measurably reduced the level of phosphate in dialysis patients (54). A crossover trial to compare vegetarian and meat diets showed that one week of a vegetarian diet significantly reduced serum phosphate and FGF-23 levels while still containing the same amount of protein as a meat diet (55).

Nutritional education. Importantly, phosphate restriction is not the only restriction that CKD patients need to adhere to. In many cases, the patients become confused or overwhelmed, and personalized nutritional education is thus important (47). Instructions to patients could be simplified by asking them to avoid excess protein intake by consuming more foods of plant origin, and less fast foods, ready-to-eat meals and carbonated drinks. The use of functional foods such as low-phosphorus milk, cheese and soy sauce may provide more food choices for patients under these restrictions. Studies have shown that education significantly reduces serum phosphate levels in hemodialysis patients (56, 57). Contrary to these findings, however, it has been reported that nutritional education does not affect calcium-phosphate levels $(58,59)$. Thus, the effect of dietary education remains controversial, and further studies are needed in this area.

Is there a lack of awareness, and how do we manage it? We have previously documented the levels of awareness of dietary phosphate intake among future medical professionals such as medical and nursing students, and in patients undergoing hemodialysis using the same questionnaire, and have found that the majority of the students were unaware that fast food and soda drinks contain phosphate additives (60). By contrast, $46 \%$ of the patients undergoing hemodialysis were aware that a high-phosphate diet is harmful, although additionally they were unaware that fast food and soda drinks contain phosphate additives (24). When patients are introduced to maintenance hemodialysis, they are usually advised to reduce dietary phosphate intake and many are prescribed phosphate-lowering medications. In the study, most of the patients undergoing dialysis chose the answers "I want to get more information about phosphate" and "I want to reduce consumption of phosphate-containing food and drinks," after they had completed the questionnaire 
(24). Their interest and willingness to change their dietary habits suggest that the intake of phosphate can be reduced if proper education programs are provided. Such programs could reduce total phosphate intake without requiring any pill burden or compromise in nutritional status.

\section{Conclusion}

In order to reduce phosphate burden, awareness of its dietary sources is indispensable. Appropriate nutritional education may lead to the better control of phosphate in patients with $\mathrm{CKD}$, and therefore to a better prognosis. It may also benefit the general population who has normal kidney function. Knowledge of phosphate additives, phosphate bioavailability and the phosphate-to-protein ratio would be helpful information in this respect. More research is obviously required in the future to produce reasonable clinical recommendations and better nutritional education. Finally, dietary phosphate toxicity is becoming a global health concern, and without measures in place to regulate optimal dietary intake, it is likely to induce harmful effects on the health of both diseased and healthy individuals (61).

\section{Conflicts of Interest}

The Authors have no conflicts of interest to declare.

\section{Acknowledgements}

The Authors thank Prof. Shawkat Razzaque (Department of Pathology, Lake Erie College of Osteopathic Medicine) for his valuable advices.

\section{References}

1 Razzaque MS: Osteo-renal regulation of systemic phosphate metabolism. IUBMB Life 11: 240-247, 2011.

2 Ohnishi M and Razzaque MS: Dietary and genetic evidence for phosphate toxicity accelerating mammalian aging. FASEB J 24: 3562-3571, 2011.

3 Brown RB and Razzaque MS: Dysregulation of phosphate metabolism and conditions associated with phosphate toxicity. Bonekey Rep 4: 705, 2015.

4 Da J, Xie X, Wolf M, Disthabanchong S, Wang J, Zha Y, Lv J, Zhang $\mathrm{L}$ and Wang H: Serum phosphorus and progression of CKD and mortality: A meta-analysis of Cohort Studies. Am J Kidney Dis 66: 258-265, 2015.

5 Block GA, Klassen PS, Lazarus JM, Ofsthum N, Lowrie EG and Chertow GM: Mineral metabolism, mortality, and morbidity in maintenance hemodialysiss. J Am Soc Nephrol 15: 2208-2218, 2004.

6 Eddington H, Hoefield R, Sinha S, Chrysochou C, Lane B, Foley RN, Hegarty J, New J, O'Donoghue DJ, Middleton RJ and Kalra PA: Serum phosphate and mortality in patients with chronic kidney disease. Clin J Am Soc Nephrol 5: 2251-2257, 2010.
7 Levin A, Stevens L and McCullough PA: Cardiovascular disease and the kidney. Tracking a killer in chronic kidney disease. Postgrad Med 111: 53-60, 2002.

8 Voormole N, Noordzij M, Grootendorst DC, Beetz I, Sijpkens YW, van Mansen JG, Boeschoten EW, Huisman RM, Krediet RT and Dekker FW: PREPARE study group. High plasma phosphate as a risk factor for decrine in renal function and mortality in predialysis patients. Nephrol Dial Transplant 22: 2909-2916, 2007.

9 Kidney Disease Improving Global Outcomes (KDIGO) CKDMBO Work Group: KDIGO clinical practice guideline for the diagnosis, evaluation, and treatment of Chronic Kidney DiseaseMineral and Bone Disorder (CKD-MBD). Kidney Int Suppl 113: S1-130, 2009.

10 Eknoyan G, Levine A and Levin NW: Bone metabolism and disease in chronic kidney disease. Am J Kidney Dis 42: 1-201, 2003.

11 Hruska K, Mathew S, Lund R, Fang Y and Sugatani T: Cardiovascular risk factors in chronic kidney disease: does phosphate qualify? Kidney Int 79121: S9-13, 2011.

12 Ohnishi M, Nakatani T, Lanske B and Razzaque MS: In vivo genetic evidence for suppressing vascular and soft-tissue calcification through the reduction of serum phosphate levels, even in the presence of high serum calcium and 1,25-dihydroxyvitamin d levels. Circ Cardiovasc Genet 2: 583-590, 2009.

13 Kestenbaum B, Sampson JN, Rudser KD, Patterson DJ, Seliger SL, Young B, Sherrad DJ and Andress DL: Serum phosphate levels and mortality risk among people with chronic kidney disease. J Am Soc Nephrol 16: 520-528, 2005.

14 Tonelli M, Sacks F, Pfeffer M, Gao Z and Curhan G; Cholesterol and Recurrent Events Trial Investigators: Relation between serum phosphate level and cardiovascular event rate in people with coronary disease. Circulation 112: 2627-2633, 2005.

15 Foley RN, Collins AJ, Herzog CA, Ishani A and Kaira PA: Serum phosphorus levels associate with coronary atherosclerosis in young adults. J Am Soc Nephrol 20: 397-404, 2009.

16 London GM, Fabiani F, Marchais SJ, de Vernejoul MC, Guerin AP, Safar ME, Metivier F and Llach F: Uremic cardiomyopathy: an inadequate left ventricular hypertrophy. Kidney Int 31: 9731980, 1987.

17 Ritter CS and Statopolsky E: Phosphate toxicity in CKD: the killer among us. Clin J Am Soc Nephrol 11: 1088-1100, 2016.

18 Amann K, Törnig J, Kugel B, Gross ML, Tyralla K, El-Shakmak A, Szabo A and Ritz E: Hyperphosphatemia aggravates cardiac fibrosis and microvascular disease in experimental uremia. Kidney Int 63: 1296-1301, 2003.

19 Itkonen ST, Karpb H, Kemi CE, Kokkonen EM, Saamio EM, Pekkinen MH, Kaekkaeinen MUM, Laitinen EKA, Turanlahti MI and Lamberg-Allardt CJE: Association among total and food additive phosphorus intake and carotid intima-media thickenssa cross-sectional study in a middle-aged population in Southern Finland. Nutr J 12: 94, 2013.

20 Ramirez-Morros A, Minerva Granado-Casas M, Alcubierre N, Montserrat Martinez-Alonso,Jordi M, Real, Castelblanco E, Esquerda A, Cao G, Rubinat E, Hernandez M, Alonso N, Fernandez E and Mauricio D: Calcium phosphate product is associated with subclinical carotid atherosclerosis in Type 2 diabetes. J Diab Res 2017: 3498368, 2017.

21 Ferrari SL, Bonjour JP and Rizzolli R: Fibroblast growth factor-23 relationship to dietary phosphate and renal phosphate handling in healthy young men. J Clin Endocrin Metabo 90: 1519-1524, 2005. 
22 Nishida Y, Taketani Y, Yamanaka-Okamura H, Imamura F, Taniguchi A, Sato T, Shuto E, Nashiki K, Arai H, Yamamoto H and Takeda E: Acute effect of oral phosphate loading on serum fibroblast growth factor 23 levels in healthy men. Kidney Int 70: 2141-2147, 2006.

23 Burnett SM, Gunawardene SC, Bringhurst FR, Jüppner H, Lee $\mathrm{H}$ and Finkelstein JS: Regulation of C-terminal and intact FGF23 by dietary phosphate in men and women. J Bone Miner Res 21: 1187-1196, 2006.

24 Shutto Y, Shimada M, Kitajima M, Yamabe H, Saitoh Y, Saitoh $\mathrm{H}$ and Razzaque MS: Inadequate awareness among chronic kidney disease patients regarding food and drinks containing artificially added phosphate. PloS One 8: e78660, 2013.

25 Brown RB and Razzaque MS: Phosphate toxicity and tumorigenesis. Biochim Biophys Acta 1869: 303-309, 2018.

26 Lee S, Kim JE, Hong SH, Lee AY, Park EJ, Seo HW, Chae C, Doble P, Bishop D and Cho MH: High inorganic phosphate intake promotes tumorigenesis at early stage in a mouse model of lung cancer. PLoS One 10: e0135582, 2015.

27 Uribarri J: Phosphorus homeostasis in normal health and chronic kidney disease patients with special emphasis on dietary phosphorus intake. Semin Dial 20: 295-301, 2007.

28 Bringhurst FR, Demay MB, Krane SM and Kronenberg HM: Bone and mineral metabolism in health and disease. In: Harrison's principles of internal medicine 17th ed. Fauci AS, Kasper DL, Longo DL, Braunwald E, Hauser SL, Janesen JL and Loscalzo J. (eds.). Mc Graw Hill, New York pp. 2365-2377, 2008.

29 Kestenbaum B and Drueke TB: Disorders of calcium, phosphate, and magnesium metabolism. In: Comprehensive clinical nephrology 4th ed. Floege J, Johnson RJ and Feehally J (eds.). Elisevier, St Louis, pp. 130-148, 2008.

30 Dasgupta I, Shroff R, Bennett-Jones D, McVeigh G and NICE Hyperphosphataemia Guideline Development Group: Management of hyperphosphataemia in chronic kidney diseases: summary of National Institute for Health and Clinical Excellence (NICE) guideline. Nephron Clin Pract 124: 1-9, 2013.

31 Ziolkowska $\mathrm{H}$ : Minimizing bone abnormalities in children with renal failure. Paediatr Drugs 8: 205-222, 2006.

32 Wolf M: Update on fibroblast growth factor 23 in chronic kidney disease Kidney Int 82: 737-747, 2012.

33 Urakawa I, Yamazaki Y, Shimada T, Iijima K, Hasegawa H, Okawa K, Fujita T, Fukumoto S and Yamashita T: Klotho converts canonical FGF receptor into a specific for FGF-23. Nature 444: 770-774, 2006.

34 Isakova T, Wahl P, Vargas GS, Gutierrez Om, Scialla J, Xie H, Appleby D, Nessel L, Bellovich K, Chen J, Hamm L, Gadegbeku C, Horwitz E, Townsend RR, Anderson CA, Lash JP, Hsu Cy Leonard MB and Wolf M: Fibroblast growth factor is elevated before parathyroid hormone and phosphate in chronic kidney disease. Kidney Int 79: 1370-1378, 2011.

35 Gutierrez OM, Januzzi JL, Isakova T, Laliberte K, Smith K, Collerrone G, Sawar A, Hoffmann U, Coglianese E, Christenson $\mathrm{R}$, Wang TJ, deFilippi $\mathrm{C}$ and Wolf M: Fibroblast growth factor23 and left ventricular hypertrophy in chronic kidney disease. Circulation 119: 2545-2552, 2009.

36 Faul C, Amaral AP, Oskouei B, Hu MC, Sloan A, Asakova T, Gutierrez OM, Aquillon-Prada R, Lincoln J, Hare JM, Mundel P, Morales A, Scialla J, Fischer M, Soliman EZ, Chen J, Go AS, Rossa SE, Nessel L, Townsend RR, Feldman HI, St John Sutton M, Ojo A, Gadegbeku C, Di Marco GS, Reuter S, Kentrup D,
Tiemann K, Brand M, Hill JA, Moe OW, Kuro-O M, Kusek Jw, Keane MG and Wolf M: FGF23 induces left ventricular hypertrophy. J Clin Invest 121: 4393-4408, 2011.

37 Guitierrez OM, Mannstadt M, Isakova T, Rauh-Hain JA, Tamez H, Shah A, Smith K, Lee H, Thadhani R, Juppner H and Wolf M: Fibroblast growth factor 23 and mortality among patients undergoing hemodialysis. N Engl J Med 359: 584592, 2008.

38 Forster RE, Jurutka PW, Hsieh JC, Haussler CA, Lowmiller CL, Kaneko I, Haussler MR and Ken Whitfield G: Vitamin D receptor controls expression of the anti-aging klotho gene I mouse and human renal cells. Biochem Biophys Res Commun 414: 557-562, 2011.

39 Sakan H, Nakatani K, Asai O, Imura A, Tanaka T, Yoshimoto S, Iwamoto N, Kurumatani N, Iwano M, Nabeshima Y, Konishi N and Saito Y: Reduced renal alpha-klotho expression in CKD patients and its effect on renal phosphate handling and vitamin D metabolism. PLoS ONE 9: e86301, 2014.

40 Zheng S, Chen Y, Zheng Y, Zhou Z and Li Z: Correlation of serum levels of fibroblast growth factor 23 and klotho protein levels with bone mineral density in maintenance hemodialysiss patiens. Euro J Med Res 23: 18, 2018.

$41 \mathrm{Hu}$ MC, Kuro-o M and Moe OW: Klotho and chronic kidney disease. Contrib Nephrol 180: 47-63, 2013.

42 Nista A, Toutouza M, Machairas N, Mariolis A, Philippou A and Koutsilieris M: Vitamin D in cardiovascular disease. In Vivo 32: 977-981, 2018.

43 Lynch KE, Lynch R, Curhan GC and Brunelli SM: Prescribed dietary phosphate restriction and survival among hemodialysis patients. Clin J Am Soc Nephrol 6: 620-629, 2011.

44 Fouque D, Horne R, Cozzolono $\mathrm{M}$ and Kalantar-Zadeh K: Balancing nutrition and serum phosphorus in maintenance dialysis. Am J Kidney Dis 64: 143-150, 2014.

45 Shinaberger CS, Greenland S, Kopple JD, Van Wyck D, Mehrota $\mathrm{R}$, Kovesdy CP and Kalantar-Zadeh K: Is controlling phosphorus by decreesing dietry protein intake beneficial or harmful lin persons with chronic kidney disease? Am J Clin Nutr 88: 1511$1518,2008$.

46 Karavetian M, Eizein H, Rizk R and de Vries N: Nutritional education for management of osteodystrophy: Impact on serum phosphorus, quality of life, and malnutrition. Hemodial Int 20: 432-440, 2016.

47 Piccoli GB, Moio MR, Fois A, Sofronie A, Gendroz L, Cabiddu G, D'Alessandro C and Cupisti A: The diet and hemodialysiss dyad: Tree eras, four open questions and four paradoxes. A narrative review, towards a personalized, patient-centered approach. Nutients, 2017. doi:10.3390/nu9040372 [Epub ahead of print]

48 Noori N, Kalantar-Zdeh K, Kovesdy CP, Bross R, Benner D and Kopple JD: Association of dietary phosphorus intake and phosphorus to protein ratio with mortality in hemodialysis patients. Clin J Am Soc Nephrol 5: 683-692, 2010.

49 Kalantar-Zadeh K: Patient education for phosphorus management in chronic kidney disease. Patient Prefer Adherence 7: 379-390, 2013.

50 Kalantar-Zadeh K, Gutekunst L, Mehrotra R, Kovesdy CP, Bross R, Shinaberger CS, Noori N, Hirschberg R, Benner D, Nissenson $\mathrm{AR}$ and Koppie JD: Understanding sources of dietary phosphorus in the treatment of patients with chronic kidney disease. Clin J Am Soc Nephrol 5: 519-530, 2010. 
51 Moore LWDNolte JV, Gaber AO and Suki WN: Association of dietary phosphate and serum phosphorus concentration by levels of kidney function. Am J Clin Nutr 102: 444-453, 2015.

52 MaCure ST, Chang AR, Selvin E, Rebholz CM and Appel LJ: Dietary sources of phosphorus among adults in the United States: Results from NHANES 2001-2014. Nutrients 9: pii: E95, 2017.

53 Ritz E, Hahn K, Ketteler M, Kuhlmann MK and Mann J: Phosphate additives in food--a health risk. Dtsch Arztebl Int 109: 49-55, 2012.

54 Sullivan C, Sayre SS, Leon JB, Machekano R, Love TE, Porter D, Marbury $M$ and Sehgal AR: Effect of food additives on hyperphosphatemia among patients with end-stage renal disease: a randomized controlled trial JAMA 301: 629-635, 2009.

55 Moe SM, Zidehsarai MP, Chambers MA, Jackman LA, Radcliffe JS, Trevino LL, Donahue SE and Asplin JR: Vegetarian compared with meat dietary protein source and phosphorus homeostasis in chronic kidney disease. Clin J Am Soc Nephrol 6: 257-264, 2011.

56 Shi YX, Fan XY, Ham HJ, Wu QX, Di HU, Hou YH and Zhao $Y$ : Effectiveness of a nurse-led intensive educational programe on chronic kidney failure patients with hyperphosphataemia: randomized controlled trial. J Clin Nurs 22: 1189-1197, 2013.

57 Tsai WC, Yang JY, Luan CC, Wang YJ, Lai YC, Liu LC and Peng YS: Additional benefit of dietitian involvement in dialysis staffs-led diet education on uncontrolled hyperphosphatemia in hemodialysiss patients. Clin Exp Nephrol 20: 815-821, 2016.
58 Schlatter S and Ferrans CE: Teaching program effects on high phosphorus levels in patients receiving hemodialysiss. ANNA J 25: 31-36, 1998.

59 Lim E, Hyun S, Lee JM, Kim S, Lee MJ, Lee SM, Oh YS, Park I, Shin GT, Kim H, Morisky DE and Jeong JC: Effects of education on low-phosphate diet and phosphate binder intake to control serum phosphate among maintenance hemodialysis patients: A randomized controlled trial. Kidney Res Clin Prac 37: 69-76, 2018.

60 Shutto Y, Shimada M, Kitajima M, Yamabe H and Razzaque MS: Lack of awreness among future medical professionals about the risk of consuming hidden phosphate-containing processed food and drinks. PLoS One 6: e29105, 2011.

61 Erem S and Razzaque MS: Dietary phosphate toxicity: An emerging global health concern. Histochem Cell Biol, 2019. doi: 10.1007/s00418-018-1711-8. [Epub ahead of print]

Received October 12, 2018

Revised October 23, 2018

Accepted October 24, 2018 